\title{
Typology of Agrarian Structure on Transmigration Land to Achieve Agrarian Transformation
}

\author{
Aryuni Salpiana Jabara, Marsuki Iswandi ${ }^{\mathrm{b}}$, Anas Nikoyan ${ }^{\mathrm{c}}$, Jamaluddin Hos ${ }^{\mathrm{d}}$ \\ aDepartment of Social Welfare Halu Oleo University, Kendari, Indonesia. E-mail: aryuni@uho.ac.id \\ bepartment of Agribusiness, Halu Oleo University, Kendari, Indonesia. E-mail: marsuki.iswandi@uho.ac.id \\ ${ }^{\mathrm{c} D e p a r t m e n t ~ o f ~ A g r i c u l t u r a l ~ E x t e n s i o n, ~ H a l u ~ O l e o ~ U n i v e r s i t y, ~ K e n d a r i, ~ I n d o n e s i a . ~}$ \\ E-mail: anaszakiah@gmail.com \\ ${ }^{\mathrm{d}}$ Department of Sociology, Halu Oleo University, Kendari, Indonesia. E-mail: jamaludin_hos@uho.ac.id
}

Article History: Received: 11 January 2021; Accepted: 27 February 2021; Published online: 5 April 2021

\begin{abstract}
Land ownership and land mastery are two things that build rural structures in the community. In the peasant community, the Agrarian structure becomes the determinant of other aspects of life, such as agricultural production rate, income level as well as economic and other social factors. The importance of Agrarian structure in the peasant community makes researchers conduct a study aimed at analysing the typology of the Agrarian structure of transmigrant farmers in South Konawe Province of Southeast Sulawesi through a combination of ownership aspects and mastery aspects. This research used qualitative methods by taking one case, namely in the Transmigration Settlement Unit (UPT) Arongo in Southeast Sulawesi Province. The results showed that through the combination of aspects of land ownership and land mastery as a form of Agrarian structure, there are three typologies of Agrarian structure form in the UPT. Arongo, owning and mastering agricultural land, owning but not mastering land and not owning but mastering land. To achieve Agrarian transformation, the ideal typology of Agrarian structures for peasant communities is in the form of Agrarian structures in which people own land while mastering it so that land management is optimal.
\end{abstract}

Keywords: Agrarian Structure, Agrarian Transformation, Transmigration Land.

\section{Introduction}

An Agrarian society is a society that depends on the agricultural sector (Pandit, 2017). The Agrarian structure is fundamental to the Agrarian society. Agrarian structures are an essential concern for agriculture and rural communities around the world (Burja et al., 2020). The Agrarian structure gives an idea of how the form and division of ownership, possession and utilization of agricultural land. Through an Agrarian structure, it can be understood the territorial configuration, namely how the distribution and the use of the territory. Through Agrarian structures, power relations, land use concentrations, fragmentation and land-use changes can be known (Córdoba et al., 2020).

The two central points of discussion of Agrarian structures are ownership and mastery of Agrarian objects. Ownership leads to formal control based on legality, whereas mastery is more widespread than ownership because Agrarian objects can be mastering without having legal legitimacy; this leads to effective control (operational). Today, the question of land ownership has assumed great significance amid several pressing problems (Moroni, 2018). Land mastery is being governed by two competing forces with one pushing flexibility of land use as a market resource and the other leading farming families to seek the security of identity. As market forces make most farms out of business as economic units, the desire to maintain family identity compels historically farming families to hold on to farmland, with the consequent development of land rental markets (while maintaining control over the resource) providing a solution to both issues (Forbord et al., 2014).

Each community has a different type of Agrarian structure to each other. In Asia, for example, Agrarian structures tend to depict large-scale plantation owners and tenants dominating the level of Agrarian structures. At the same time, East Asian countries such as Korea and Taiwan, small and medium-sized agriculture dominates its Agrarian structure (Oyvat, 2016). Agrarian structures in China are also different where there are two recognized forms of land ownership, urban land under state ownership and rural land owned by farmers collectively (Huang et al., 2017; Tong et al., 2021). California itself is also different. Its Agrarian structure is more complicated than federal, state and local ownership (Easterday et al., 2018). Nearly Similar to other Agrarian areas, Agrarian structures on transmigration land in UPT. Arongo describes a unique form of Agrarian structure. The unique format of the Agrarian structure is the result of social relations that occur among the community. Ownership, control and coordination of essential prospects in location-based transformation (Bryson et al., 2017).

The importance of Agrarian structure for the peasant community, as well as the unique Agrarian structure that exists in each farmer community, makes researchers interested in researching how the typology of Agrarian structure in the transmigration community, especially in UPT. Arongo. Furthermore, researchers are working to discuss how the ideal Agrarian structure to achieve Agrarian transformation.

\section{Research Methods}


The study used qualitative methodologies, which seek to reveal and understand the unknown (Sutrisno et al., 2020). This study tried to explain causal processes that occurred over a long period and seeks to establish theoretical models of comprehensive structures and large-scale processes that govern social life with systematic historical investigations and comparisons (Bauerly, 2017; Asaka \& Awarun, 2020). The research strategy used is a case study. The case raised in this study is a transmigration program with restrictions on the community of transmigrant farmers. This research was carried out on the transmigration area located in South Konawe Regency, UPT. Arongo as one of the existing transmigrant community settlement units since 2010. The selection of the location is based on the complexity of agricultural problems that occurred at the site of the study based on the Agrarian structure that exists at the site. Also, the complexity of the situation in the location still happens to this day, so the results of the research that will be produced later can provide additional science that is more up to date.

The informants in this study were chosen purposively or deliberately, namely the informants who are considered the best informants and believed to be able to provide information following the objectives that want to be achieved in research consisting of members of the transmigrant community, village devices, local governments and related agencies who are considered to have authority in Agrarian reform programs or transmigration programs, and other informants involved in the transmigration program. In this study, data collection techniques were conducted using several ways: In-depth interviews, observations, and documentation in the form of archive footages, images, videos and so on. Data analysis is carried out by identifying the distribution of ownership and possession (Noibi et al., 2020) of Agrarian objects (land), the way the item is acquired, the legitimacy of the land ownership and control (proof of ownership of land rights (ownership) or other forms (mastery), as well as the social relationship order of existing structural patterns.

\section{Results and Discussions}

Transmigration program in UPT. Arongo has been going since 2010 with three waves of placement of transmigrant farmers. Related to Agrarian structure, the two things that make up the Agrarian structure of the community are land ownership and land mastery. In terms of ownership, there is a distribution of land ownership in UPT. Arongo. By the rules of transmigration land distribution, each farmer should get an area of 2 hectares per head of a family consisting of yardland, business land 1 and business land 2. Implementation of the transmigration program in UPT. Arongo showed that all transmigrated participants both placements in 2010, 2011 and 2012 were not entirely gained business land 2. Besides, many of the transmigrants who should get a division of the land of 1 Ha per Family Head for yard land and business 1, instead get a division of less than 1 ha. There is even a Head of Family who does not get the division of business land 1 at all. This land ownership inequality is further exacerbated by the unilateral use of some of the migrant land claimed to be in the land of palm oil plantations, PT. Merbau. A total of 99 (ninety-nine) head of families who transmigrated in 2011 were claimed by the oil palm company PT. Merbau.

Problems were related to land ownership distribution in UPT. Arongo both the division of real estate and the work to the community per year placement will be described in a summary in Table 1.

Table 1. Land Ownership Distribution in UPT. Arongo

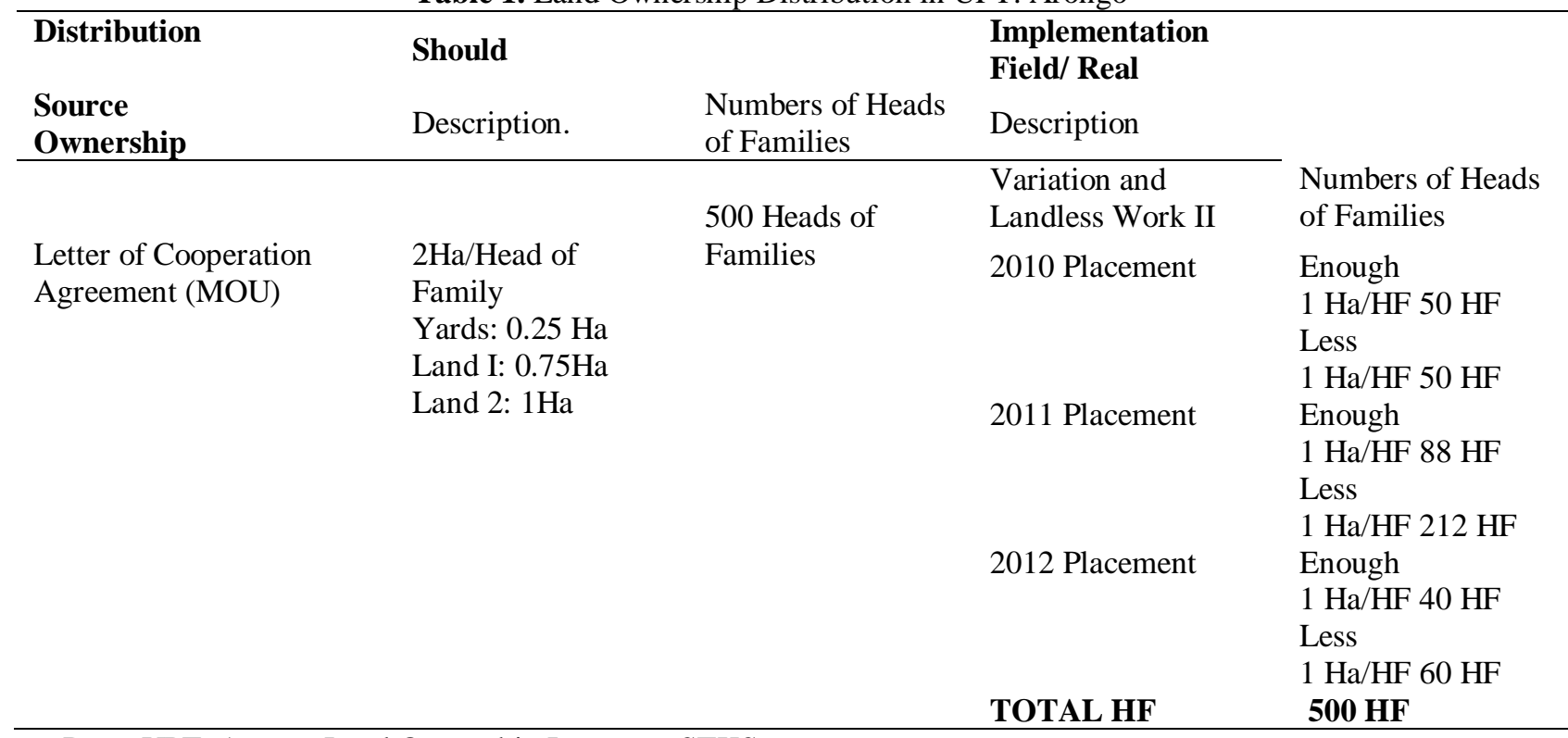

Data: UPT. Arongo Land Ownership Inventory STKS. 
The lack of transmigration distribution land to transmigrant families is still controversial among the transmigrant community because the conversion of land for 2 with one calf is the government's answer to the lack of land distribution. The government claims that the promised land or land of 2 hectares has been distributed but converted in the form of cattle distribution. This led to the criticism of transmigrants who stated that some residents did not receive cow assistance, the community who received cow assistance also said that there was no prior notice that the cow aid will substitute the land 2. According to the Transmigrants, the calf that became an aid could not be compared to be a substitute for the supposedly The land 2. Even if it is to be converted, then the price of the calf should worth the price of 2 lands that they should receive.

In terms of land ownership, distribution land ownership that exists in UPT. Arongo should be in full control by the transmigrant members stationed in the UPT. Arongo. Either a member of the local transmigrants or a member of transmigrants from outside the region by the Letter of Placement. But currently land ownership in UPT. Arongo is no longer entirely in the control of transmigrants. Some transmigrants who received land distribution at the beginning of the placement still control the land by processing the ground. But some have no control over the land that should be managed.

Land ownership distribution pattern on the UPT. Arongo no longer follows the initial design of being controlled by transmigrant farmers, both transmigrants and local transmigrants. Supposed you look at the history of land ownership in the UPT. Arongo, should then it showed that the one ruled the land is only transmigrant farmers. However, by now, there are a lot of lands on the UPT. Arongo controlled by Non-immigrant farmers. Take into consideration, that currently the land that has been maintained and processed by palm oil companies which supposedly not own the land in the block I, now could control, process and even expel transmigrant farmers from their land. At least 99 lands in the block I that should be controlled by transmigrant farmers is claimed by the oil palm plantations so that the land is now controlled by PT. Merbau.

In addition to the land in the block I controlled by oil palm plantations, some land has also switched their mastery to non-farmers from outside the UPT. Arongo. This happened through buy and sell mechanism conducted by farmers at UPT. Arongo. The scheme of buy and sell land is inevitable amid the inability of transmigrant members to meet the needs of their families who depend solely on land or the habit of selling land from local transmigrant members. In addition, the presence of sago trees in the land of transmigrant farmers is the determinant of whether the land is controlled by transmigrants or controlled by the local community. The land in which there is sago plant mastery is in the hands of local people because the sago plant claimed to be a plant planted by ancestors or parents of the current Tolaki ethnicity.

From the Agrarian structure on the land in PT Arongo Law, based on the source and evidence of ownership and mastery, it can be typologically three forms of Agrarian structure that existed in UPT land. Arongo:

1. Owning and Mastering, which is a resident that corresponds to the Letter of Placement given the land and until now still processing the land owned. So, they are free to manage the land.

2. Owning but not Mastering, the land in Block I, whereas their land is enclosed with the land owned by PT. Merbau palm oil company. Based on the advertisement of The Letter of Placement they should have the land, but because claims by palm oil company it made the transmigrants unable to process the land to the point many migrants leave their land and choose to return back. They feel unable to do much and feel uncertainty in managing land obtained according to the Letter of Placement.

3. Not Owning but Mastering. This is the model drawn based on the ability of palm oil companies to access multiple transmigration land that is included in the company's work even though the company itself has not obtained land ownership rights from the government. In this case, the company did not own the land, but they were able to control the land by working on the claimed land. In addition, the scheme does not own but master, is a pattern owned by Tolaki ethnic locals who claimed the planted sago corps in the middle of the land as the land of their ancestors.

A quick overview of the typology of Agrarian structures in the UPT. Arongo and its existing forms of Agrarian relations will be presented in Table 2.

Table 2. Typology of Agrarian Structure and Agrarian Social Relations form in UPT Transmigration land. Arongo Based on Ownership and Mastery Aspects

Agrarian Structure

Agrarian Subjects

1. Transmigrant Community in general

\section{Ownership}

Legality and Resources

Land Ownership Rights, Letter

of Placement, Letter of

Cooperation Agreement and

certificate management through

PTSL

\section{Mastery \\ Proof of Power and \\ Resources}

Plants they plant in transmigration land as well as buildings
Typology

Owning \&

Mastering 
2. Some Transmigrants Block I

3. Local People

4. Private plantations
Land Ownership Rights, Letter of Placement, Letter of Cooperation Agreement and certificate management through PTSL

No legality

Only Permissions Allocated
Cannot be processed or forced to leave because it is cultivated by oil palm plantations

Recognized sago plants planted by parents Cultivated land, even planted with palm oil Not by farmers

Source: Field Data

\section{Discussion}

Displacement programs produce new ways to organize the productive and reproductive activities of humans and the rest of the world (Marley, 2016). However, administrative and territorial reforms have a direct impact on the development of the Agrarian sector (Mykhailova et al., 2018). Farmers certainly ensure the availability of land to work on.Recent research on several key dimensions of Agrarian transformation also alludes to demographic problems and changes in the population structure of society (Choenkwan \& Fisher, 2018; Watanabe, 2017). The distribution of land ownership is one of the important factors of agricultural productivity and economic well-being of farmers and also affects their social and political status in the community (Naseer, 2016). However, the location of the transmigration must take into account all aspects, including the distance reached the area (Miyamoto, 2006). State support and attention increase farmer productivity (Chigumira, 2018). Because there is a system of government that favors the bourgeois class more than smallholders (Vergara-Camus \& Kay, 2017). In fact, the strength and development of farmers have important implications for economic and social development (Bauerly, 2017; Jeon, 2011).

Transmigration is an effort to improve the Agrarian structure and indirectly will have an impact on food security. Agrarian structure contributes to food production and security structure (Alexandri \& Luca, 2014). Like how land accumulation can change Agrarian social relations(Sajadian, 2020). Ultimately the Agrarian structure will boil down to Agrarian transformation. Agrarian transformation means a change in the agricultural system in a more advanced direction. (Bossenbroek et al., 2015). In contrast to Agrarian transformation, Transition Agrarian occurs when society transitions from one production mode to another (Sugden, 2020). The picture of the countryside today, instead of being an Agrarian transformation, a lot of farmland is hardly profitable, but farmers continue to work on it; agriculture provides only a fraction of household income; the land is loaned to relatives without reward; rural populations are still subsistence; and rice cultivation persists even though young people are not interested in farming (Nguyen et al., 2020). It shows the slow Agrarian transformation characterized by increasing rural migration to urban areas and low agricultural productivity (Reta, 2016).

The land is the main asset of farmers (van den Bold et al., 2015).Thus, if looking at the basis of the Agrarian structure on land ownership and mastery, then it is not enough to just move farmers but must also guarantee land ownership and mastery. Agrarian transition occurs when society transitions from one production mode to another (Sugden, 2020).

Therefore, to achieve Agrarian transformation as the ultimate goal of Agrarian reform, typology ideal structure Agrarian is that the farmer community at the same time should be able to master its agricultural land so that the management of agricultural land can be optimal. Based on data obtained from the UPT. Arongo, the three typologies of Agrarian structures mentioned are owning and controlling, owning but not controlling, and have but not master. If you see Table 2, then it can be seen that the land is well managed depending on its ownership and mastery. Well-managed land is land owned and controlled by farmers, while the land in which farmers do not control is not optimal management and unable to be processed or excavated because of disputes and controlled by other parties. Psychologically, ownership is the key to preservation of natural resources (Preston \& Gelman, 2020). In addition, ownership also increases people's willingness to protect and oppose exploiting natural areas (Preston $\&$ Gelman, 2020). So that in an alternative image where farmers as local landowners and rulers, then they can play an important role in the effort to form a region (Bryson et al., 2017). Farmers can be strong local actors and can control the land (Kansanga et al., 2020). land ownership by peasant families encourages the transformation of productive relationships by developing collective production areas (Córdoba et al., 2020).

\section{Conclusions and Suggestions}




\section{Conclusions}

From the results of the above discussion, it can be concluded that there are three typologies of Agrarian structures that exist at the UPT transmigration site. Arongo namely: (1) Owning and Mastering, residents who comply the Letter of Placement given the land and until now still cultivate the land owned. So, they are free to manage the land. (2) Owning but not Mastering the land in Block I whereas their land is enclosed with the land owned by PT. Merbau palm oil company. Based on the advertisement of the Letter of Placement they should have the land but because claims by palm oil company then the transmigrants cannot process the land even many migrants leave their land and choose to return home/home. They feel they unable to do much and feel there is uncertainty on the processed land acquired according to the Letter of Placement. (3) Not Owning but mastering which referred to the model drawn on the ability of palm oil companies to access multiple transmigration land that is included in the company's work even though the company itself has not obtained Land Ownership Rights from the government. In this case, the company did not own the land, but able to control the land by working on the claimed land. In addition, the scheme does not own but master, is a pattern owned by Tolaki ethnic locals who claimed the planted sago corps in the middle of the land as the land of their ancestors.

\section{Suggestions}

From the conclusion of the study, it is necessary to improve the Agrarian structure on all type of mastery and ownership of transmigration land, in order to create an optimal land management and able to achieve both the expected results and Agrarian transformation in accordance with the ideals. For the procurement of land in the next transmigrate program, it is worth to notes: First, pay attention to the land where the transmigration program is implemented. The land must be ensured that it is no longer disputed or overlapped with any party, especially the local people. If the transmigration land is still related to the local people, then it will be a stone in the implementation of transmigration in the field. What should be considered is the implementation of land distribution to the transmigrant community must follow the plan that has been made before. For example, marking transmigrants on a location and a map that has been confirmed. Third, the area given is in accordance between the one on the field and what supposed to be received. Fourth, legal certainty and legality over the land given to be atop concern so the community feels safe and comfortable to manage the land they received. Fifth, the improvement of the Agrarian structure can also be made through transmigration land management scheme if the land overlaps with private land. That is, to put the interests of the transmigrant party first given that the transmigrant party consists of many heads of families, from hundreds to thousands. Sixth, to arrange the land that has switched functions to others who are not transmigrated is an effort to improve the structure that needs to be done. This is because the transmigration land should not be transferred to the other party.

\section{Acknowledgements}

Researchers thank the community of transmigrant farmers in UPT. Arongo and others who are willing to provide data and information related to this research.

\section{References}

6. Alexandri, C., \& Luca, L. (2014). Implications of Agrarian Structures upon the Agricultural Supply in Romania. Procedia Economics and Finance, 8(14), 17-24. https://doi.org/10.1016/s22125671(14)00057-4

7. Asaka, D.S., \& Awarun, O. (2020). Understanding Mechanistic Explanation as A Strategy of Analytical Sociology. Indonesian Journal of Social and Environmental Issues (IJSEI), 1(3), 192-198. https://doi.org/10.47540/ijsei.v1i3.55.

8. Bauerly, B. (2017). The Agrarian seeds of empire: The political economy of agriculture in US state building. Studies in Critical Social Sciences, 100, 1-322.

9. Bossenbroek, L., Van Der Ploeg, J.D., \& Zwarteveen, M. (2015). Broken dreams? Youth experiences of agrarian change in Morocco's Saïss region. Cahiers Agricultures, 24(6), 342-348. https://doi.org/10.1684/agr.2015.0776

10. Bryson, J.R., Mulhall, R.A., Song, M., \& Kenny, R. (2017). Urban assets and the financialisation fix: Land tenure, renewal and path dependency in the city of Birmingham. Cambridge Journal of Regions, Economy and Society, 10(3), 455-469. https://doi.org/10.1093/cjres/rsx013

11. Burja, V., Tamas-Szora, A., \& Dobra, I. B. (2020). Land concentration, land grabbing and sustainable development of agriculture in Romania. Sustainability (Switzerland), 12(5). 
https://doi.org/10.3390/su12052137

12. Chigumira, E. (2018). Political ecology of agrarian transformation: The nexus of mining and agriculture in Sanyati District, Zimbabwe. Journal of Rural Studies, 61, 265-276. https://doi.org/10.1016/j.jrurstud.2017.11.003

13. Choenkwan, S., \& Fisher, M. (2018). Introduction to the special section: Agrarian transformation in Thailand - commodities, landscapes, and livelihoods. Forest and Society, 2(2), 112-120. https://doi.org/10.24259/fs.v2i2.5356

14. Córdoba, C., Triviño, C., \& Calderón, J. T. (2020). Agroecosystem resilience. A conceptual and methodological framework for evaluation. PLoS ONE, 15(4), 1-20. https://doi.org/10.1371/journal.pone.0220349

15. Easterday, K., McIntyre, P., \& Kelly, M. (2018). Land ownership and 20th century changes to forest structure in California. Forest Ecology and Management, 422, 137-146. https://doi.org/10.1016/j.foreco.2018.04.012

16. Forbord, M., Bjørkhaug, H., \& Burton, R.J.F. (2014). Drivers of change in Norwegian agricultural land control and the emergence of rental farming. Journal of Rural Studies, 33, 9-19. https://doi.org/10.1016/j.jrurstud.2013.10.009

17. Huang, D., Huang, Y., Zhao, X., \& Liu, Z. (2017). How do differences in land ownership types in China affect land development? A case from Beijing. Sustainability (Switzerland), 9(1). https://doi.org/10.3390/su9010123

18. Jeon, S. (2011). Mechanisms of labor transition during agricultural transformation: The cases of South Korea and Indonesia. Proceedings of International Conference on Asia ..., 13, 21-26.

19. Kansanga, M.M., Ahmed, A., Kuusaana, E.D., Oteng-Ababio, M., \& Luginaah, I. (2020). Of waste facility siting and relational geographies of place: Peri-urban landfills, community resistance and the politics of land control in Ghana. Land Use Policy, 96, 104674. https://doi.org/10.1016/j.landusepol.2020.104674

20. Marley, B.J. (2016). The Coal Crisis in Appalachia: Agrarian Transformation, Commodity Frontiers and the Geographies of Capital. Journal of Agrarian Change, 16(2), 225-254. https://doi.org/10.1111/joac. 12104

21. Miyamoto, M. (2006). Forest conversion to rubber around Sumatran villages in Indonesia: Comparing the impacts of road construction, transmigration projects and population. Forest Policy and Economics, 9(1), 1-12. https://doi.org/10.1016/j.forpol.2005.01.003

22. Moroni, S. (2018). Property as a human right and property as a special title. Rediscussing private ownership of land. Land Use Policy, 70, 273-280. https://doi.org/10.1016/j.landusepol.2017.10.037

23. Mykhailova, L., Stoyanets, N., Mykhailov, A., Kharchenko, T., \& Bachev, H. (2018). Sustainable development of the Ukrainian agrarian sector: perspectives and challenges. Problems and Perspectives in Management, 16(3), 28-39. https://doi.org/10.21511/ppm.16(3).2018.03

24. Naseer, A. (2016). Current Status and Key Trends in Agricultural Land Holding and Distribution in Punjab, Pakistan: Implications for Food Security. Journal of Agricultural Studies, 4(4), 14. https://doi.org/10.5296/jas.v4i4.9670

25. Nguyen, T.A., Gillen, J., \& Rigg, J. (2020). Economic transition without agrarian transformation: the pivotal place of smallholder rice farming in Vietnam's modernisation. Journal of Rural Studies, 74, 8695. https://doi.org/10.1016/j.jrurstud.2019.12.008

26. Noibi, T.O., Murrieta, R.L.M. \& Pandey, D. (2020). The Resurgence of Informal Settlements in Cuidad Juarez: Estrella Sol del Poniente, Causes and Conditions. Indonesian Journal of Social and Environmental Issues (IJSEI), 1(2), 79-90. https://doi.org/10.47540/ijsei.v1i2.26

27. Oyvat, C. (2016). Agrarian Structures, Urbanization, and Inequality. World Development, 83, 207-230. https://doi.org/10.1016/j.worlddev.2016.01.019

28. Pandit, R. (2017). Agrarian Transformation in Rural Society, 9, 627-637.

29. Preston, S. D., \& Gelman, S. A. (2020). This land is my land: Psychological ownership increases willingness to protect the natural world more than legal ownership. Journal of Environmental Psychology, 70, 101443. https://doi.org/10.1016/j.jenvp.2020.101443

30. Reta, H.B. (2016). Population dynamism and agrarian transformation in Ethiopia. African Journal of 
Agricultural Research, 11(39), 3863-3879. https://doi.org/10.5897/ajar2014.8959

31. Sajadian, C. (2020). Critical Agrarian Studies. In International Encyclopedia of Human Geography (What is the second, 3. Elsevier. https://doi.org/10.1016/b978-0-08-102295-5.10456-1

32. Sugden, F. (2020). Agrarian Transformations. In International Encyclopedia of Human Geography (What is the second, 1. Elsevier. https://doi.org/10.1016/b978-0-08-102295-5.10448-2

33. Sutrisno, H., Hardiman, G., Pandelaki, E. E., \& Susi, T. (2020). Acculturation of structure and construction in the houses of balinese migrants (case study: Basarang Jaya Village, Central Kalimantan). International Journal on Advanced Science, Engineering and Information Technology, 10(2), 837-842. https://doi.org/10.18517/ijaseit.10.2.3772

34. Tong, D., Yuan, Y., \& Wang, X. (2021). The coupled relationships between land development and land ownership at China's urban fringe: A structural equation modeling approach. Land Use Policy, 100, 104925. https://doi.org/10.1016/j.landusepol.2020.104925

35. Van Den Bold, M., Dillon, A., Olney, D., Ouedraogo, M., Pedehombga, A., \& Quisumbing, A. (2015). Can Integrated Agriculture-Nutrition Programmes Change Gender Norms on Land and Asset Ownership? Evidence from Burkina Faso. Journal of Development Studies, 51(9), 1155-1174. https://doi.org/10.1080/00220388.2015.1036036

36. Vergara-Camus, L., \& Kay, C. (2017). The agrarian political economy of left-wing governments in Latin America: Agribusiness, peasants, and the limits of neo-developmentalism. Journal of Agrarian Change, 17(2), 415-437. https://doi.org/10.1111/joac. 12216

37. Watanabe, K. (2017). The Agrarian Transformation in Northeastern Thailand: A Review of Recent Research. Southeast Asian Studies, 6(2), 293-306. https://doi.org/10.20495/seas.6.2 